\title{
Integration Versus Fragmentation, the Role of Minor Rural Networks in Rural Cultural Landscapes. A Study-Case in Spain
}

\author{
Julio Plaza Tabasco and Héctor S. Martínez Sánchez-Mateos *(D) \\ Department of Geography and Land Planning, Faculty de Letras, Campus de Ciudad Real, \\ University of Castilla-La Mancha, 13071 Ciudad Real, Spain; Julio.Plaza@uclm.es \\ * Correspondence: HectorS.Martinez@uclm.es; Tel.: +34-926-295300-6865
}

Citation: Tabasco, J.P.;

Martínez Sánchez-Mateos, H.S.

Integration Versus Fragmentation, the

Role of Minor Rural Networks in

Rural Cultural Landscapes. A

Study-Case in Spain. Sustainability

2021, 13, 4765. https://doi.org/

$10.3390 /$ su13094765

Academic Editor: Alejandro Rescia

Received: 30 March 2021

Accepted: 20 April 2021

Published: 23 April 2021

Publisher's Note: MDPI stays neutral with regard to jurisdictional claims in published maps and institutional affiliations.

Copyright: (c) 2021 by the authors. Licensee MDPI, Basel, Switzerland. This article is an open access article distributed under the terms and conditions of the Creative Commons Attribution (CC BY) license (https:/ / creativecommons.org/licenses/by/ $4.0 /)$.

\begin{abstract}
This work deals with the dichotomy between integration and fragmentation caused by artificial elements in the cultural landscapes, especially minor rural roads. In Europe, the rural matrix dominates the configuration of landscapes, and the agents of fragmentation can be analysed from different perspectives. For this purpose, the Land Parcel Information System, designed for the Common Agriculture Policy (CAP) is used as a data source to feed the indicators, allowing a high detail analysis, down to the parcel unit. It is applied to a case-study in Spain: the province of Ciudad Real. Here we find different landscape units with different rural and agrarian profiles to test the hypothesis. We use three indicators that allow us to explore the configuration of different cultural landscapes under the fragmentation perspective, using minor rural roads and other elements of the rural matrix that can only be observed at large scale. Then we calculate a composite indicator summarizing the fragmentation results of each unit. Results reveal a significative variability of fragmentation results regarding the land use and spatial patterns of the different cultural landscapes dominated by agrarian and rural factors, with a strong correspondence with the minor rural network underneath. Therefore, fragmentation can be interpreted as a dual process in cultural landscapes where the different land uses have different relations with the infrastructure network.
\end{abstract}

Keywords: minor rural networks; landscape fragmentation; agricultural landscapes; spatial indicators; Land Parcel Information System (LPIS)

\section{Introduction}

The basic premise of this research is that rural roads are ambivalent elements in cultural landscapes: while they are responsible for territorial functionality and the cohesion of spaces at the local/landscape scale, their presence leads to fragmentation and internal division of the landscape. Our main objective is to study the role of minor rural road network from the perspective of cultural landscapes and as an expression of the processes that fragment and integrate them.

For decades, the concept of landscape has been constructed from an integrated perspective, implementing structural and functional approaches. The European Landscape Convention (ELC) helped to consolidate this approach, introducing the social dimension as a relevant aspect, bringing importance to perception and human intervention in landscapes [1] and, consequently, emphasising the need for landscape planning and management [2]. In Europe, the landscape is characterised by the strong influence of the interaction between natural conditions and the agricultural use of the territory [3], forming for the most part a mosaic of cultural landscapes, a combination of natural and social aspects.

The road network is strongly interdependent with the rest of land uses of landscapes, since its essential function is to provide the best possible connectivity between places and activities, but at the same time it generates impacts in the ecological sphere, essentially fragmenting landscape units. The integrity and continuity of the units in which the landscape is arranged and differentiated is considered an essential factor in the balance 
and sustainability of such units [4], which is why fragmentation is one of the impacts in landscape units usually related to the road network, reducing them to smaller pieces and generating discontinuity in their constituent elements [5-7]. Therefore, landscape fragmentation is a process defined by the breaking of habitats into smaller subunits, reducing the spatial continuity of their elements [8,9].

The aim of this article is to analyse the role of minor rural roads in the structure of agrarian cultural landscapes and to assess fragmentation as part of its character. By their nature, roads are at the same time agents of integration and fragmentation, while facilitating the connection between land uses and contributing to an increase in the internal division of landscapes. However, the dynamics in the European rural matrix open an interesting debate on the character of this dichotomous process between integration and fragmentation, which coexists at the same time with the duality between the fragmentation and defragmentation of cultural landscapes [10]. We focus our analysis on the minor rural network, composed as the sum of rural roads, livestock routes, touristic trails and footpaths. This network is important at a local scale, but also has dichotomic role on landscape function and fragmentation. We differentiate major infrastructures from minor rural network. The former are built following technical and legal prescriptions and use materials that affects wildlife crossing (fenced areas) and soil permeability (asphalt, concrete, etc.). On the contrary, the minor rural network is, in its majority, a network without an artificial coverage that usually contributes to absorption and permeability.

At the level we propose to focus on, scale plays a major role. The scale of work on the territory has traditionally been determined by the type of data available or the technical requirements for managing large volumes of data. At present; however, scale and its constraints are not limiting for landscape or other geographical studies, although any type of research must be rational in the way it handles information [11]. We aim to remain as close as possible to the actions of the actors involved in landscape fragmentation. It is at these scales that we can mostly avoid the errors hidden by aggregation. We have therefore decided to use the Land Parcel Identification System (LPIS, SIGPAC (https:/ /www.mapa.gob.es/es/agricultura/temas/ sistema-de-informacion-geografica-de-parcelas-agricolas-sigpac-/defaultaspx, (accessed on 22 April 2021)) developed for Common Agricultural Policy (CAP) management [12].

We develop our objectives by focusing on two specific aspects developed by two Research Questions (RQ, Table 1): firstly (RQ1), we will try to understand the importance of the minor rural road network together with other elements in the fragmentation of cultural landscapes. The design, function and use of infrastructure have a substantive effect on both the structure and character of landscapes and are factors in transformation and/or abandonment [5]. As a result, we introduce the methodological factor linked to the most appropriate fragmentation indicators to assess the impact of infrastructure elements on the landscape.

Table 1. Research Questions.

\begin{tabular}{lcl}
\hline \multicolumn{1}{c}{ Research Question } & Type & \multicolumn{1}{c}{ Objective } \\
\hline $\begin{array}{l}\text { RQ1: What is the role of the minor } \\
\text { rural network in the fragmentation } \\
\text { of cultural landscapes? }\end{array}$ & Theoretical & $\begin{array}{l}\text { Interpret fragmentation in cultural } \\
\text { landscapes and its relationship with } \\
\text { different elements (infrastructures) }\end{array}$ \\
\hline $\begin{array}{l}\text { RQ2: Is the LPIS an useful data } \\
\text { source to explore landscape } \\
\text { structure and fragmentation }\end{array}$ & Instrumental & $\begin{array}{l}\text { Explore the potential of this data } \\
\text { source to apply LP metrics }\end{array}$ \\
\hline
\end{tabular}

The second point of interest (RQ2) is the use of large-scale land use databases, in our case the LPIS, as a measure of landscape fragmentation. Thus, this instrument at the European level could have a new use in landscape and land management policies. In this paper, we will explore the opportunities of applying different fragmentation indicators and compare their usefulness. The territory where we are implementing this idea is the province of Ciudad Real (Spain, NUTS 3 ES422). 
The text unfolds as follows. After this introduction, Section 2 develops the theoretical framework that contextualises the study, starting from the relationship between the European rural matrix, cultural landscapes and landscape fragmentation and the role of rural roads in this process. Section 3 presents the case study to which we apply the proposed analysis and from which we obtain the results set out in Section 4, which are discussed in Section 5. We finish with some conclusions and avenues for future research in the sixth and final section.

\section{Theoretical Approach: Rural Matrix, Landscapes, and Fragmentation Due to Rural Roads}

The consideration of different ecological units within a landscape introduces a multifunctional perspective and the capacity of a landscape to concurrently offer multiple spaces [13] which, from the perspective of the cultural landscape, complements structural approaches and broadens the range of the concept of landscape. Cultural landscapes as socio-ecological systems combine anthropic use with natural dynamics. Different land covers, natural or agricultural, give rise to different habitat conditions and biophysical relationships that are organised in patterns and interact with one another [14,15]. Europe's spatial structure is strongly determined by human presence, and current land uses are heavily influenced by society, with an evolution characterised by periods of widespread deforestation and ploughing alongside periods of agricultural abandonment [16], all subject to the social dynamics of the territory. Consequently, cultural landscapes in Europe are essentially shaped by the agricultural variable, which is responsible for the identity of large areas of the continent and for biodiversity itself [17] (pp. 211-212).

Consequently, under this approach, in Europe we can speak of a predominance of rural landscapes, with an essentially agrarian matrix containing different configurations related to the natural characteristics (morphology, soil, climate and vegetation) and to the cultural character, embodied in the structure of land use and changes in land use. If both elements (natural and cultural) are sometimes expressed in a dichotomous or excluding way, it is correct to classify the landscape within a gradient between extremes, from the maximum density of natural factors to the artificialisation of densely urbanised spaces [18]. From this perspective, most cases will always be transitional or mixed landscapes, with contributions from all elements. In these landscapes the combination of factors is particularly relevant to understanding their structure and processes.

There is a notable body of studies that focus on the structural aspects of landscape fragmentation as a process that undermines the continuity of ecosystems and their biodiversity, to the extent that the European Environmental Agency (EEA) proposes incorporating fragmentation parameters into regional and transport planning processes [9]. Although some empirical work has found evidence that landscapes with a greater number of parts actually offer more opportunities for different species, increasing biodiversity [19,20], the interpretation of landscape fragmentation is usually negative, and it is human action that is essentially responsible for such fragmentation through the artificialisation of land, either by urbanisation [21] or transport infrastructure [22] in a degradation process identified as one of the most evident threats to landscape conservation on the continent [9].

Many studies make proposals that focus on the structural aspects of fragmentation; essentially the number, size and geometry of the different patches that make up a landscape unit $[17,22-24]$. This approach focuses on the impact of fragmentation from an ecological point of view and, in a way, assimilates three main types of elements under the concept of a mosaic: fragments, corridors and the landscape matrix [25], which relate to nature conservation [26]. The most common causes of these fragmentation processes are of human origin, creating an obstacle to the internal connectivity of natural habitats. The key drivers of this fragmentation are transport infrastructure, urban development, and the agricultural system [27].

In this sense, several studies point out that environments characterised by agricultural use also experience the negative impact of fragmentation, in an interpretation of the integration-segregation of uses [13] and the dispersion of populations that underlies current 
rural problems [21]. The integrity of rural cultural landscapes, which bring together both natural and social values, is also threatened by fragmentation processes, which usually break up traditional territorial patterns in favour of vectors of change that may come from new functions or the productive intensification of an activity [10] (p. 138). In these territories, the areas most affected by fragmentation are those linked to agricultural uses and farmland [28], but most studies work on a low, practically continental scale, and do not allow us to appreciate the differences between agricultural uses that can be found in landscapes with a strong agricultural component.

Recent decades have seen major changes in the European rural matrix, essentially linked to agricultural and forestry practices, with irreversible impacts in many cases. Two opposing trends can be observed in the agricultural context: on the one hand, the intensification of production that is gradually replacing the traditional road network with a larger-scale network that can be assimilated to hyperconnectivity; on the other hand, a trend towards land abandonment, related both to ecological factors and to soil productivity and its management systems [29] and the stagnation of more traditional activities [17], which does not necessarily lead to renaturalisation of the territory [30].

At the same time, fragmentation leads to losses in landscape connectivity [8]. Other territorial factors undergo the reverse process: they increase their connectivity, their interaction potential, they defragment [31] (p. 96). Indeed, what can be understood as a process of landscape degeneration is a process of land use change, whereby some uses increase its connectivity at the expense of others, which reduce it [17]. This includes both the natural matrix of the landscape and the cultural elements that make up the traditional European agricultural landscape.

Thus, transport infrastructure elements have the essential objective of guaranteeing the connectivity and integration of territories and are the basis on which to build the development capacity of territories [32].

Rural roads are communication routes with a local and specific functional scale, which can be analysed through large-scale databases. Rural roads are particularly significant structures for understanding the specific interrelationship between land uses. The role of rural roads is essential in the configuration and shaping of rural landscapes, from a traditional perspective as heritage elements and as agents of change towards new landscape configurations.

In landscapes with a strong agricultural component, roads show a multifunctionality that is also related to the character of the traditional landscape. They serve as a connection between agricultural uses and the different functions within them, as distributors and connectors of a local character [5], and they are fundamental to the stability and sustainability of this type of landscape. At the same time, they perform ecological functions, such as in landscapes with little natural use, where the roadside can be considered a biological reservoir [33], forming fragile and vulnerable ecosystems [34]. Given its functionality, the rural road network is an invariant factor in agricultural landscapes with a notable role in the structure and configuration of the rural matrix.

This process leads to highly specialised areas, in which the productive factor intensifies and modifies the traditional patterns of land exploitation, generating a loss of cultural values [35]. Faced with this problem of cultural loss, various initiatives have emerged for cultural agricultural landscape management, such as the Baeza Charter on agricultural heritage, which includes the conservation of rural roads [36].

Under these premises, logic demands broadening the basis of reasoning on the relationship between fragmentation and transport infrastructure, particularly in the case of purely local roads. Increased road density often fragments landscapes and is one of the main causes of fragmentation. This means a loss in ecosystem connectivity, which places the argument in a dichotomous and exclusionary situation: more anthropic connectivity means less environmental/natural connectedness. Such logic reduces the interpretative potential in the context of cultural landscapes, where empirical experience shows us that 
there are interpretative nuances that can be lost or even misinterpreted when the argument is based on the indicator.

\section{Materials and Methods}

\subsection{Study Case: The Rural Matrix in Ciudad Real (Spain)}

Our study area is the province of Ciudad Real in Spain (NUTS 3 ES422, Figure 1), in the centre of the Iberian Peninsula. It occupies an area of $19,813 \mathrm{~km}^{2}$ and includes different geomorphological domains, which will serve as the basis for the formation of different landscapes. The north-eastern area is part of the great plain of La Mancha. Geologically it consists of Tertiary sedimentary materials, which facilitate the formation of a large underground aquifer. Therefore, this is an area dedicated to irrigated crops and vineyards. The south-eastern quarter of the province is known as Campo de Montiel and is dominated by moorland and large expanses of cultivated land over secondary and tertiary geological materials. The dominant agricultural uses of cereals, vineyard, olive, and almond trees are mixed with patches of Mediterranean scrubland. The western part of the province, however, is dominated by mountain landscapes, with gentle hills and wide valleys or corridors over Palaeozoic materials with extensive olive groves and fields of cereal, pastures, and large patches of Mediterranean woodland in the higher areas. This wide diversity of landscapes explains why the province has two national parks (Las Tablas de Daimiel National Park and Cabañeros National Park), two natural parks (Lagunas de Ruidera Natural Park and Alcudia Valley and Sierra Madrona Natural Park) and a proposed geopark dedicated to volcanism (Campo de Calatrava Volcanoes). The potential for tourism is remarkable. For this reason, successful management of the rural landscapes that encompass these protected areas and proper conservation of the network of rural roads are considered strategies for diversification and sustainability in territorial development.

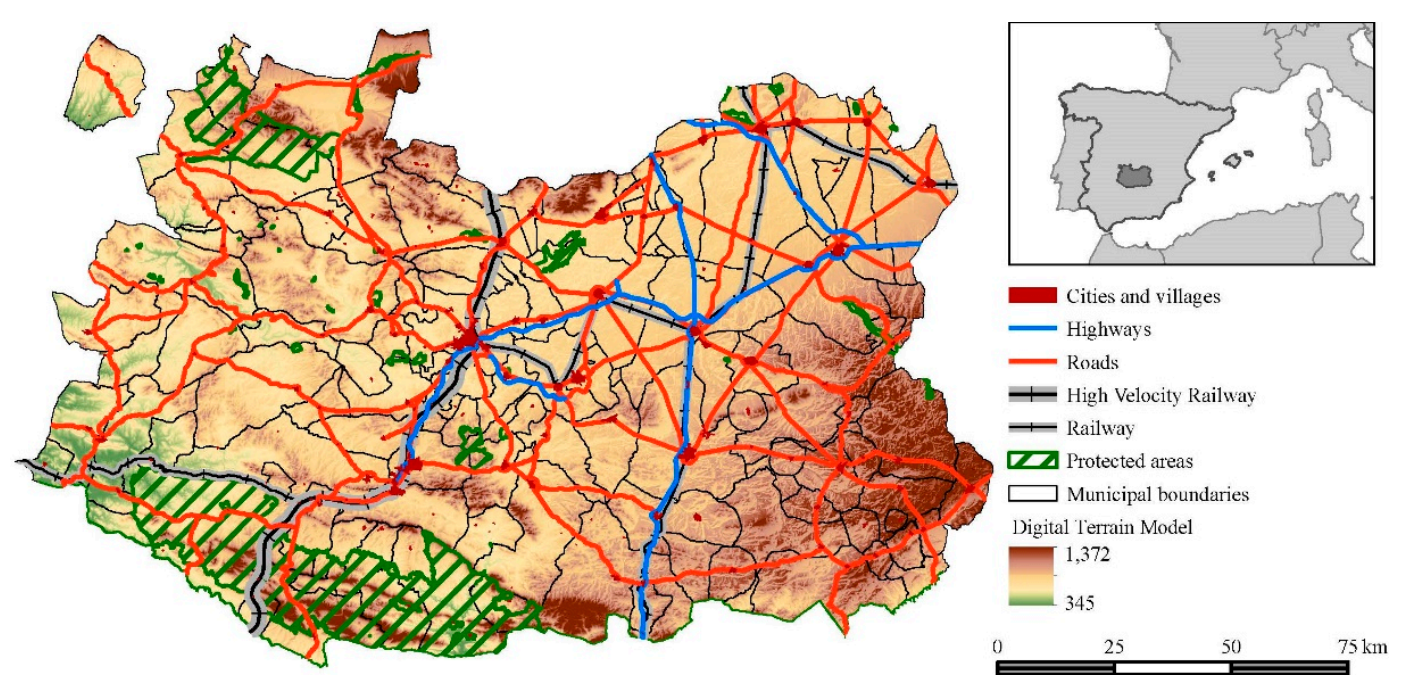

Figure 1. Location of case-study.

The dynamics of land occupation are highly dependent on historical factors related to the structure of land ownership and demographic evolution. In the province of Ciudad Real, the areas of greatest agricultural interest were settled and ploughed from the 12th century onwards, while mountainous areas or areas far from the towns were reserved in large estates for livestock and forestry use. This has led to great contrasts in land distribution and consequently in the structure of plots and landscapes. On the other hand, as has been the case in much of Europe, since the mid-20th century, rural-urban migration has been more intense in less productive agricultural areas, while in areas with greater agricultural potential and groundwater for irrigation, agricultural transformations have been very intense. Consequently, the province of Ciudad Real has three types of regions or 
comarcas: plains, transition areas and hilly areas. The first type of region is characterised by high agricultural specialisation thanks to the exploitation of groundwater [37], while the others are characterised by land abandonment, lack of productivity and ageing and migration of their population [38].

\subsection{Data Collection and Procedures}

The source of information on landscape units in the province of Ciudad Real will be the Atlas of Spanish Landscapes published by the Ministry of the Environment [39], which identifies a total of 57 landscape units summarised into 9 landscape associations. Landscape associations, according to the Atlas methodology, are groupings that integrate types that are close in topographic configuration, bioclimatic characteristics, and similarities in their organisational features in land use. A map with landscape associations and units can be consulted on Appendix A, Figure A1.

The source of information for analysing the fragmentation of landscape units is the LPIS database for the province of Ciudad Real for the year 2020. This information allows us to explore landscape unit characteristics at a very detailed scale, as it captures the infrastructure elements as surface and non-linear entities, and we can classify the uses according to several criteria that are summarised in the concept of coverage, i.e., by the biophysical properties and relationships of the use with respect to the ecological environment and human activity, such as vegetation structure, use of water for irrigation, technology and labour $[15,40]$.

The LPIS database divides the territory of the province of Ciudad Real into more than 1.3 million enclosures or parcels where land ownership is another attribute that characterises the shape of the enclosures. Therefore, before starting the calculation of fragmentation indicators, we need to manage this geodatabase to reach a map of homogeneous land use patches for each landscape unit. This work was carried out using ArcMap 10.3 software.

A first step is to add to each LPIS area its Landscape Unit code, which will be one of the criteria for the generalisation or dissolution of polygons. The second step focuses on identifying and classifying the polygons of the different communications infrastructure elements. In the LPIS all such enclosures are grouped under the code "CA" (communication roads). With the help of the digital National Topographic Map at a scale of 1:25,000, we differentiated these road polygons into different categories: motorways, railways, main roads, secondary roads, and what we called the minor rural network, including rural roads, livestock routes, touristic trails and footpaths. Then we added a level of occlusion characterising the limitation of movement or traffic according to each category (Table 1). Thus, occlusion level 1 indicates a complete impediment to transversal mobility as it is closed by fences parallel to the infrastructure, which only happens on motorways and high-speed railways, while in the rest of the cases the occlusion weights the higher or lower level of traffic.

In the third step we continue classifying the remaining land uses. Following Table 2, we group land uses according to their level of occlusion, understood as a barrier or level of human presence (from irrigated greenhouses to dry crops to natural spaces). Information on agricultural water use is significant to differentiate more intensive land cover and land use. From the point of view of landscape structure, we distinguish between herbaceous, shrub, and tree crops and natural vegetation.

The occlusion exerted by agricultural land uses is established according to the labour required by each type of crop. However, this level of occlusion could be improved if we consider certain management systems in the cases of super-intensive vineyards and olive groves, where the fields are trellised, which significantly alters the quality of the landscape and its occlusion. 
Table 2. Main criteria used to aggregate patches.

\begin{tabular}{|c|c|}
\hline Main Land Use Associations (LPIS) & Description \\
\hline Urban zones, airports, solar plants, buildings & $\begin{array}{l}\text { Places cause complete occlusion because fencing or urban } \\
\text { function itself }\end{array}$ \\
\hline $\begin{array}{c}\text { Irrigated crops (greenhouses, intensive trellis vineyard and } \\
\text { olive grove, orchards) }\end{array}$ & $\begin{array}{c}\text { Irrigated land use areas add artificial elements related to greater } \\
\text { occlusion (machinery, labour, agrochemicals products) }\end{array}$ \\
\hline $\begin{array}{c}\text { Rain fed agriculture (herbaceous, vineyards, olive grove, } \\
\text { fruit trees) }\end{array}$ & Traditional agriculture and farming cause fewer occlusion \\
\hline Forestry (woodlands, scrubs, unproductive areas) & Tendency to natural configuration \\
\hline Motorway and High-Speed Railway & Complete occlusion caused by side fences \\
\hline National and regional roads and conventional railway & $\begin{array}{l}\text { High traffic rate and strong structural separation from adjacent } \\
\text { patches }\end{array}$ \\
\hline Provincial and local roads & Lower traffic rate and minor structural separation \\
\hline Minor rural network & Unpaved connections for rural purposes \\
\hline
\end{tabular}

With the information thus classified, we can dissolve the enclosures of the original database into a new one with 486,387 enclosures or patches with similar land cover $(849,500$ fewer enclosures than the original database; Figure 2 illustrates the process). This database already allows constructing the three indicators (IFI, UFI and $\mathrm{S}_{\mathrm{eff}}$ ) in addition to the composite indicator (CILF).

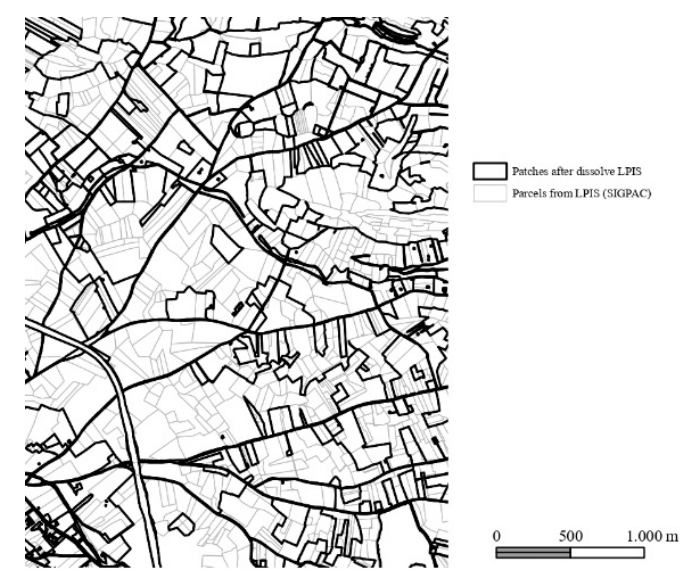

Figure 2. LPIS database management.

\subsection{Fragmentation Analysis}

There are two basic requirements for the use of indicators for landscape fragmentation analysis: clarity and simplicity [4]. For this research we used a combined fragmentation indicator following that proposed by De Montis et al. [41], who advocate developing a widely accepted combined indicator that meets the expectations of simplification in terms of usefulness in the decision-making process without losing information and interpretative potential. An effective set of indicators must be used to achieve this while also achieving interpretative diversity and complexity. To this end, these authors follow the OECD approach [42] developed empirically by Nardo and Saisana [43], arriving at a composite indicator of landscape fragmentation (CILF) approach that seeks synthesis through a single metric by selecting three specific variables or indicators, subsequently normalised and aggregated.

This formulation fits the purpose of understanding the role of rural roads, the urban settlement and the agriculture practices as it allows us to establish an aggregate of fragmenting agents with three origins: transport infrastructure (IFI), urban uses of the territory (UFI); and the division of uses $\left(\mathrm{S}_{\mathrm{eff}}\right)$. 
The Infrastructural Fragmentation Index (IFI) has been widely discussed and used in landscape fragmentation studies [44]. It offers advantages for a synthetic assessment of the fragmentation caused by communication routes. Based on their proposal, we modified the expression to adapt it to our polygon database by applying the following equation:

$$
I F I=\frac{N P \cdot\left(\sum_{1}^{n} S_{i} \cdot O_{i}\right)}{A_{t}}
$$

$N$ and $P$ relate to the number of patches and the perimeter of a landscape unit. $S_{i}$ is the area of land referenced as transport infrastructure in the LPIS, weighted by the occlusion coefficient $O_{i}$ generated by each type of road. Following the conclusions of Ledda and De Montis [44], the occlusion values are as shown in Table 3 and express the different levels of network hierarchy and their impact on the landscape units. Finally, $A_{t}$ is the total area of each landscape unit.

Table 3. Occlusion coefficients considered for IFI calculations (adapted from [41,44]).

\begin{tabular}{ccc}
\hline Type of Infrastructure & Value & Description \\
\hline Motorway and High-Speed Railway & 1.0 & Complete occlusion caused by side fences \\
\hline $\begin{array}{c}\text { National and regional roads and conventional } \\
\text { railway }\end{array}$ & 0.5 & $\begin{array}{c}\text { High traffic rate and strong structural separation } \\
\text { from adjacent patches }\end{array}$ \\
\hline Provincial and local roads & 0.3 & Lower traffic rate and minor structural separation \\
\hline Minor rural network & 0.08 & Unpaved connections for rural purposes \\
\hline
\end{tabular}

Compared to other applications of this indicator, our proposal includes two novelties. Firstly, the reference unit is the patch formed by homogeneous land use fragments from the LPIS mapping with similar levels of occlusion (structural and functional), which allows for detail in the analysis given the scale. These agricultural land use patches have been formed by merging (dissolving) all those agricultural land use enclosures with a similar level of fragmentation (Table 3). As explained above, the use of a large-scale vector database solves the limitations of interpreting satellite imagery such as Copernicus or other mapping such as Corine Land Cover, SIOSE (Sistema de Información sobre Ocupación del Suelo de España, Information System on Spanish Land Use), or Cadastral Cartography.

The second novelty is the substitution of the infrastructure elements in the model as a surface and not as a linear element, taking advantage of the possibilities offered by the data source. In addition, this allows us to include not only traditional communication infrastructure, but also the minor rural network.

The second indicator used is the Urban Fragmentation Index (UFI), which assesses the fragmentation generated by urban settlements. Its equation is [44]:

$$
U F I=\frac{\sum_{i=1}^{i=n} S_{i}}{A} \cdot \frac{\sum_{i=1}^{i=n} p_{i}}{2 \cdot \sqrt{\pi \sum_{i=1}^{i=n} S_{i}}}
$$

With respect to former uses of this variable, the novelty in our case is to include other facilities located in the rural matrix that fragment at the same level as populations (e.g., airports, solar energy production plants or the assembly of buildings and facilities scattered in the rural matrix). $S_{i}$ stands for the surface of the urban zones considered, $A$ is the total area of the landscape unit and $p_{i}$ the perimeter of the urban zones.

The third fragmentation indicator used is the Effective Mesh Density $\left(S_{e f f}\right)$, which values the subdivision of unit of reference, dividing the landscape unit by all the patches 
we have got dissolved in LPIS according to the criteria aforementioned. Mathematically, $S_{\text {eff }}$ is the inverse of Effective Mesh Size $\left(M_{\text {eff }}\right)$ :

$$
S_{e f f}=\frac{1}{M_{e f f}}
$$

Following Jaeger [45], $M_{\text {eff }}$ expresses the probability that two random points may be connected in the study area. It corresponds to the expression:

$$
M_{e f f}=\frac{1}{A_{t}} \cdot \sum_{1}^{n} A_{i}^{2}
$$

$A_{t}$ is the total area of the landscape unit and $A_{i}$ is the size of patch $i$. Consequently, $M_{\text {eff }}$ returns a result that measures the fit of the patches to the total area: the closer the patch value is to that of the landscape unit, the lower the $M_{\text {eff }}$ value and the lower the fragmentation of the landscape unit.

These metrics are integrated into a composite indicator (CILF), normalising the three indicators according to the min-max algorithm [41] (p. 5). Unlike De Montis et al. [41] we use a geometric mean, which does not allow compensation between the indicators:

$$
C I L F=\sqrt[n]{\prod_{1}^{n} I_{i}}
$$

CILF is the result of the $n$th root of the normalised product of the $i$ variables in the model. In our case, the value of $n$ is three and the indicators $i$ are IFI, UFI and $S_{\text {eff. }}$.

\subsection{Fragmentation Layers}

Given the characteristics and potential offered by the information source, we can combine different elements that allow us to obtain fragmentation layers (FL). These FLs are simply configurations of the variables that make up the IFI and UFI indicators to interpret the effect of different uses on landscape fragmentation in the study area.

The aim is to approach different geometries that allow us to interpret the impact of certain layers within each category. Jaeger et al. [27] establish geometries with different sensitivities to elements that pose differentiated obstacles, including or extracting factors from the metrics to analyse the results to these factors. This indicates fragmentation patterns or profiles based on certain starting assumptions. Similarly, we will modify the variables that feed the IFI and the UFI to explore our hypotheses (Table 4): (a) the role of rural roads on fragmentation, and (b) the fragmentation gradient generated on the rural matrix by different land uses. Through this approach, we explore the sensitivity of certain elements and then relate these layers to the patterns of the rural landscape and the units delimited by application of the ELC.

Table 4. Summary of elements used for each FL.

\begin{tabular}{ccc}
\hline Metric & FL & Fragmenting Elements Included \\
\hline \multirow{2}{*}{ IFI } & $\mathrm{IFI}_{\text {Total }}$ & All roads, railways, and pathways \\
& $\mathrm{IFI}_{\text {Paved }}$ & Only paved roads, major or minor, and railways \\
\hline \multirow{2}{*}{ UFI } & $\mathrm{UFI}_{\text {Total }}$ & Urban areas, buildings and fenced areas in the rural matrix \\
& $\mathrm{UFI}_{\text {Urb }}$ & Only urban settlements land use \\
\hline
\end{tabular}

Once the GIS layer with the patch information has been generated, it is possible to operate with it to obtain the fragmentation metrics by combining the different elements that make up each FL. Within IFI we use two different hypotheses: 
1. IFI $I_{\text {Total }}$ would be the indicator containing all the fragmentation infrastructure elements, incorporating all polygons dedicated to a transport use: paved roads, railways, and unpaved minor rural network.

2. IFI $I_{\text {Paved }}$ considers only paved roads and railways, whatever their hierarchy. These roads have a higher scale connectivity function, since in the most basic case they are intermunicipal roads, but more frequently we find roads at the regional and national scale.

Comparing the two metrics will help us understand the value of the rural road network. With respect to UFI we establish two layers of interpretation related to the influence that certain land uses have on fragmentation:

3. UFI Total fully incorporates the fragmenting agents derived from urbanisation, including all the typology considered and reflected in Table 2, which incorporates elements that are not frequent in these analyses.

4. UFI $I_{U r b}$ only considers polygons labelled as urban zones within the source and aims to detect the influence of settlements in the context of the different polygons and, subsequently, their relationship with the landscape units.

\section{Results}

In this section, we present and display the most relevant elements concerning the approach of this study. The summarized results obtained by applying the methodology and sources outlined above can be consulted on Appendix B, Table A1.

\subsection{Infrastructure Fragmentation Index (IFI)}

In our LPIS database we counted an area of 38,973.82 hectares occupied by communication routes, approximately $1.96 \%$ of the total area. This area is divided between paved roads and railways (11,930.10 ha; $69.38 \%$ ) and rural roads (27,043.72 ha; $30.62 \%)$. Although roads and railways have a greater impact on fragmentation than rural roads, these also contribute to fragmentation, which is what we intend to measure here.

In general, the province shows a significant differentiation between the eastern area, with greater agricultural use and the presence of motorways and railway lines, and the western area where land ownership is more concentrated and land use alternates between agricultural and natural. We can see a west-east gradient in the $I F I_{\text {Total }}$ (Figure 3), from less to more fragmentation. The eastern units show a higher value of the indicator, especially those located in the north and related to the areas of plains and intensive agricultural uses. In contrast, the western units (Figure 3), within the foothill and mountain domains, offer less fragmentation. The large unit coded 62.13 (see map on Figure A1. Appendix A) shows the highest result, followed by other plain units in the province. It is showing a relation between topography, road density and urban system. Landscape fragmentation by rural roads is very high due to the intense distribution of property since the 12th century and its use for arable crops and vineyards since the end of the 19th century. This process enhances the presence of rural roads accessing the properties and tend to consolidate fragmentation caused by agricultural accessibility.

In addition, $I F I_{\text {Paved }}$ was calculated including only paved roads and railway lines. Comparing the two IFIs, we can see interesting differences at the level of landscape association, shown in Table 4. Since $I F I_{\text {Paved }}$ regards a part of the infrastructures, its value will be always lower than $I F I_{\text {Total }}$ and the difference points out the impact of the minor rural network. Hence, the greater the difference the more impact caused by unpaved and rural roads. Results shown in Table A1 (Appendix B) are the average score of each indicator, while Figure 4 expresses the ratio between the two IFI indicators applied to each landscape unit and relates them to the number of patches, ultimately showing the contribution of rural roads to the fragmentation of the units and the different distribution of this difference across landscape units, not only in terms of superficial continuity, but also considering that unpaved infrastructures allows better soil permeability and water absorption. The difference between indicators were calculated dividing $I F I_{\text {Paved }}$ by $I F I_{\text {Total }}$, 
expressed in percentage. This shows the proportion that the paved roads contribute to the total fragmentation.

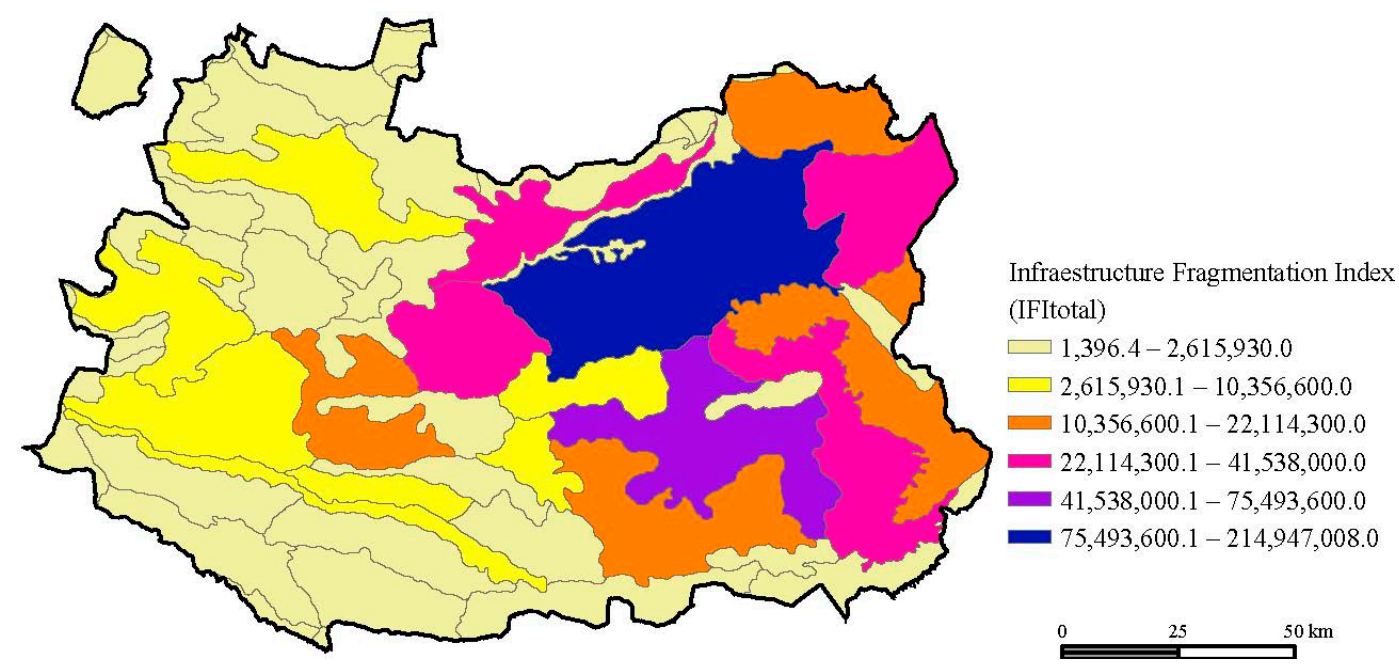

Figure 3. Infrastructure Fragmentation Index results, 2020 (Source: LPIS Data classification by natural breaks in ArcMap 10.3).

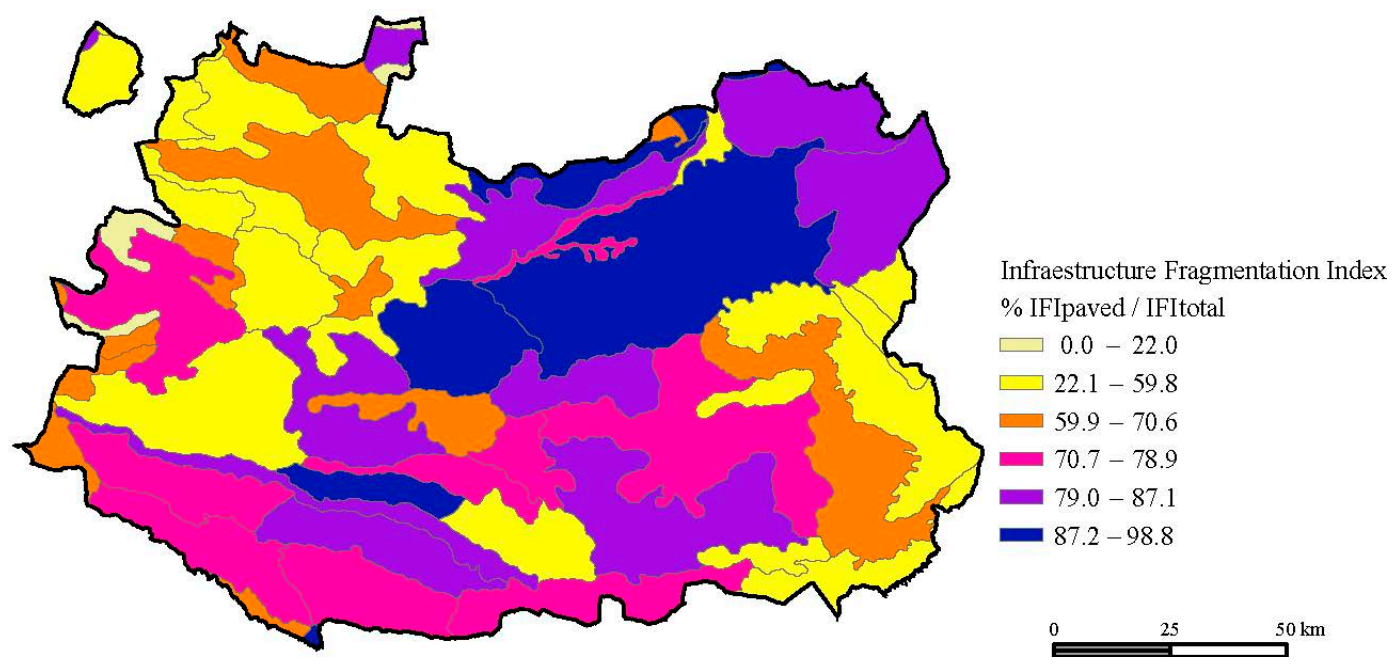

Figure 4. Difference between $\mathrm{IFI}_{\text {Paved }}$ and $\mathrm{IFI}_{\text {Total, }} 2020$ (Source: LPIS. Data classification by natural breaks in ArcMap 10.3).

The most significant difference appears in units related with moorlands, plateaus, and pastures, while plain units show the smallest difference. This means that for rural landscapes (i.e., Campo de Montiel (units 53.24, 62.19, 77.13 in Figure A1) compared to La Mancha (units 62.06, 62.10, 62.13, 62.15, 62.16, 62.17, 62.18 in Figure A1)), the weight of roads is significant in measuring fragmentation and/or cohesion when there is no equivalent road network (there are more roads and railways in La Mancha than in Campo de Montiel). This interpretation is confirmed when looking at the "Corridors", where there is also a remarkable presence of "strong" infrastructure elements (see the Brazatortas-Puertollano corridor, unit 46.10 in Figure A1).

The fewest difference is showed by the landscape unit called "Llanos de Ciudad Real" (a plain in the centre of the province, unit 62.15 in Figure A1). This unit hosts the main city and capital of the province, organising and concentrating the infrastructure network.

\subsection{Urban Fragmentation Index (UFI)}

The UFI results are reflected in Figure 5, highlighting population density and economic activities. Therefore, units with cities and non-agrarian activities score the most on this indi- 
cator. The landscape units "Llanos de Ciudad Real" (unit 62.15) and "Corredor BrazatortasPuertollano" (unit 46.10) stand out with higher results. The former corresponds to an inland plain that contains the provincial capital, Ciudad Real, a small conurbation of approximately 100,000 inhabitants. This unit also includes facilities with a high impact on the landscape, such as the Ciudad Real airport and development and leisure projects abandoned after the 2008 crisis, such as "El Reino de don Quijote", which currently maintains a small golf course. The second unit of note in UFI is the Brazatortas-Puertollano corridor where we find the city of Puertollano (46,607 inhabitants) and its former mining facilities, an oil refinery and other energy activities (photo $=$ https: $/ /$ puertollano.repsol.es $/$ es $/$ index.cshtml (accessed on 22 April 2021)). The provincial map shows the north-eastern sector as the next most fragmented area, due to the presence of small and medium-sized urban centres such as Daimiel, Manzanares, Tomelloso and Alcázar de San Juan, with large industrial areas and energy plants that fragment the rural matrix. On the other hand, peripheral units, especially in the north-west, show fewer UFI, stressing the rural character and the smaller population density of these areas.

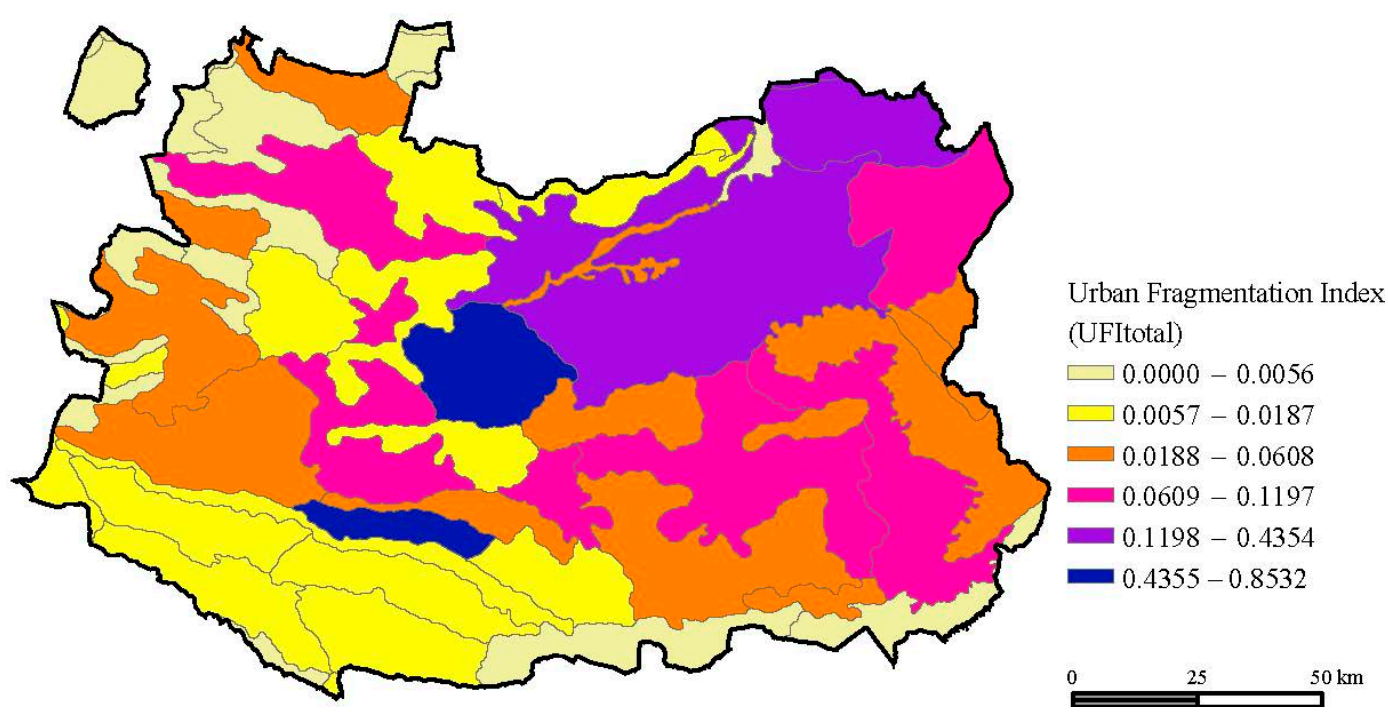

Figure 5. Urban Fragmentation Index results, 2020 (Source: LPIS. Data classification by natural breaks in ArcMap 10.3).

A second FL was calculated derived from UFI $\left(U F I_{U r b}\right)$, and its difference with $U F I_{\text {Total }}$ is depicted on Figure 6. A score of $100 \%$ means that urban fragmentation is caused only by urban areas surveilled from municipalities, and smaller percentages indicates the influence in UFI of other built-in elements (isolated buildings, fenced parcels). The greatest influence of non-urban elements (lower percentage) is shown in vegas (flood meadows and riverbanks, unit 57.13). Flood meadows are peculiar landscape units, with shapes and sizes very close to the river paths with barely presence of human settlements of any kind because of the flood risk.

Two units show the highest percentages: (a) "Sierra de Calatrava" (unit 27.13), related to the Puertollano urban area (the second city in the province); and (b) "Sierra del Chorito" (unit 17.04), where the National Park of Cabañeros is located. In this latter, the presence of scattered buildings is minimum, and the main centre of Horcajo de los Montes town is basically the only urban settlement in the unit. 


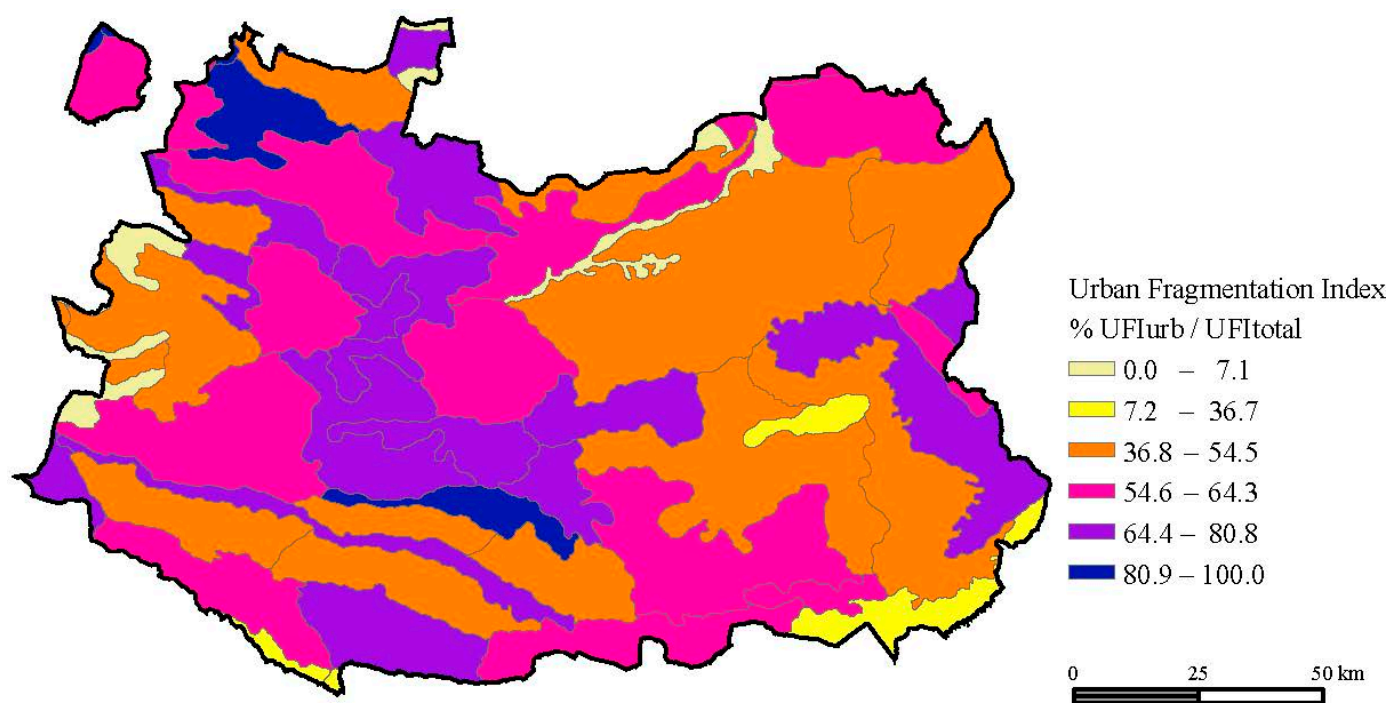

Figure 6. Difference between $\mathrm{UFI}_{\mathrm{Urban}}$ and $\mathrm{UFI}_{\mathrm{Total}}, 2020$ (Source: LPIS. Data classification by natural breaks in ArcMap 10.3).

\subsection{Effective Mesh Density (Seff)}

$S_{\text {eff }}$ measures internal subdivision and lack of internal cohesion in structural terms. Results (Appendix B, Table A1. Figure 7) show that landscape units with a greater distribution of land ownership and a greater diversification of agricultural land use are more fragmented according to this indicator. This is the case of the landscape units "Llanos de Socuéllamos-Villarrobledo" (unit 62.06), "Llanos de Turleque-Madridejos" (unit 62.10) and "Llanos Lillo-Villacañas" (62.16), all of them belong to the association called "Llanos interiores" (inland plains), with a widely distributed plot of land dedicated to vineyards, fruit trees, olive trees and arable crops. Once again, $S_{\text {eff }}$ differentiates the province into two well-defined sectors: eastern and western. Within the eastern sector, we observe that the central area does not have the same level of fragmentation as the surrounding plains due to the greater concentration of land and a certain specialization in agricultural crops that generate more uniform and extensive landscape patches.

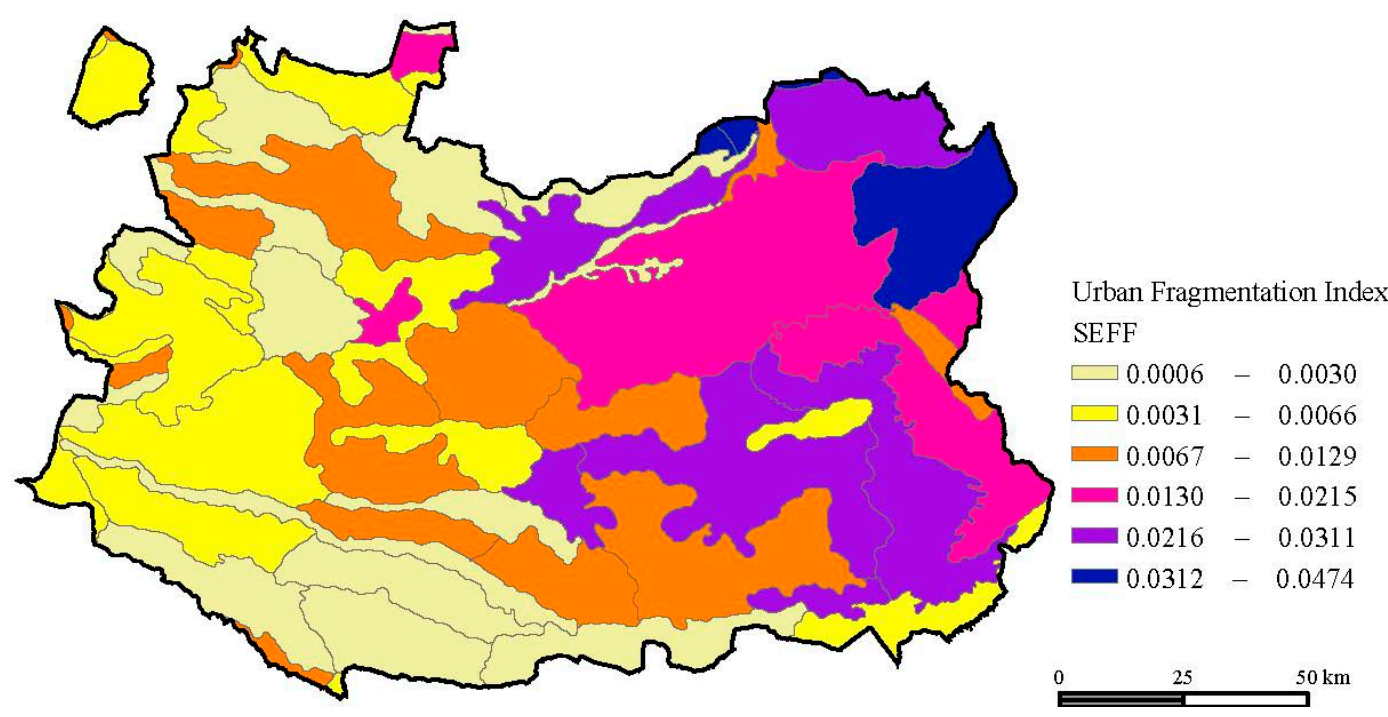

Figure 7. Effective Mesh Density results, 2020 (Source: LPIS. Data classification by natural breaks in ArcMap 10.3).

In the west, land ownership is more concentrated and there is less diversity of agricultural uses; mainly rain-fed cereals and olive groves with abundant areas of maquis and Mediterranean woodland. They therefore have lower levels of fragmentation than in the east. 


\subsection{Composite Indicator of Landscape Fragmentation (CILF)}

Figure 8 shows the results of the composite indicator. In the province of Ciudad Real, CILF suggests that the most fragmented area is the landscape unit "Llanos de Ciudad Real en Manzanares-Daimiel-Tomelloso" (unit 62.13), in the centre-east of the province. This unit already had the highest fragmentation in IFI. Its high score is explained by a strong concentration of infrastructure (including minor rural network), small and medium-sized towns, and an average fragmentation of the territory due to agricultural activities which tends to land ownership concentration and intensive uses. In the province, the association called "Llanos interiores" (inland plains) remain the most fragmented in terms of land use. Urban pressure and agricultural intensive activities together with a higher density of roads and railway lead to these results.

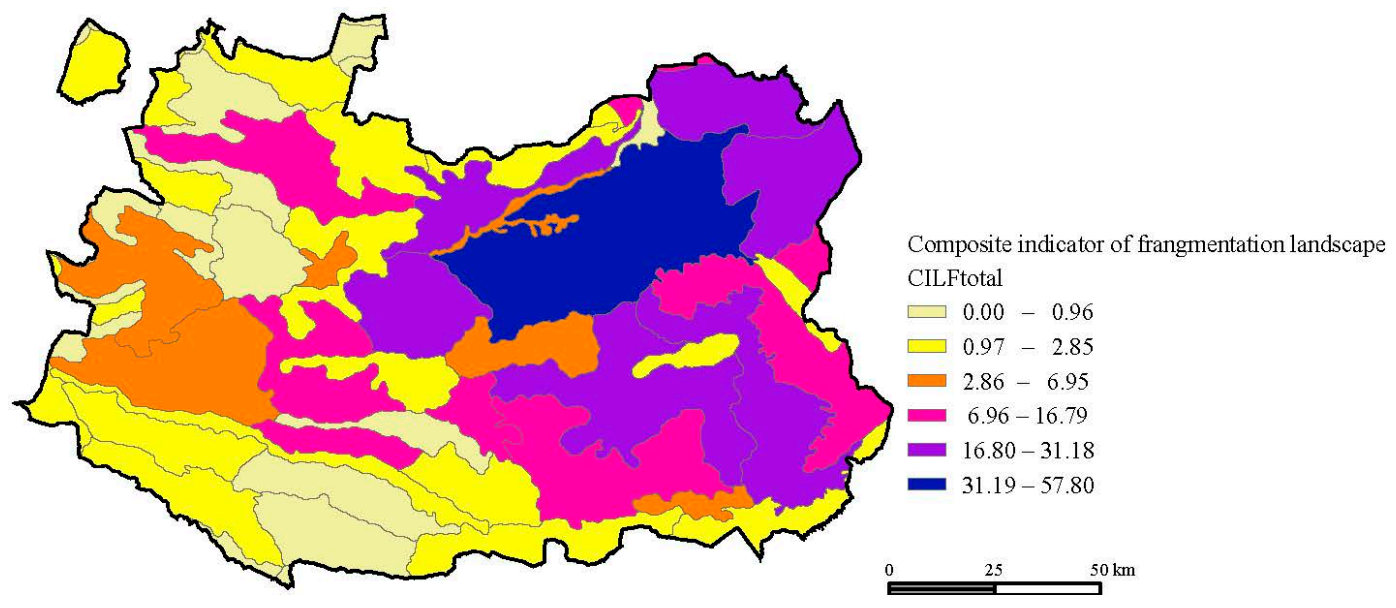

Figure 8. Composite Indicator of Landscape Fragmentation, 2020 (Source: LPIS. Data classification by natural breaks in ArcMap 10.3).

An intermediate situation appears mainly in units in the south and west of the province, principally related to transitional landscapes, with important urban settlements and transport infrastructures, but with a less dynamic and intensive agrarian system. The lowest fragmentation appears in the north-west, with mountain landscapes with more input of natural assets and more traditional rural uses. These areas are, as well, those units with higher proportion of minor rural roads in the spatial system.

\section{Discussion}

The first research question (RQ1) dealt with the dual role of the rural road network, both fragmenting in its condition of anthropic infrastructure, but also with an important role in rural matrix connectivity and its sustainability, consequently, valuing a cultural, agrarian, and traditional landscape. To solve this approach, we developed a battery of indicators that are able to assess fragmentation concisely and separated into different fragmentation elements, thus enabling us to isolate the role of rural roads from other infrastructure elements. We were able to compare IFI indicators with and without minor rural roads at the landscape unit scale. The difference between IFI indicators shows a high sensitivity to this variable, with contributions between 12 and $50 \%$ to the overall result, with higher proportion of minor rural roads contributing to fragmentation in landscape units with more traditional profiles (less dynamic agriculture, lower population density and urban functions). In addition to the quantitative impact, it is relevant to talk about the qualitative interpretation of the results, which affect the structure and configuration of the different agricultural domains and landscapes. Traditional rural matrix is more present in those units where the minor rural network has a more impact in landscape fragmentation.

To delve deeper into this discourse, we took advantage of the potential of the information source to also incorporate the different land uses that allow us to establish different 
agrarian models, either related to intensive and transforming territory dynamics (which fragment the cultural landscape) or related to traditional characteristics within the so-called rural matrix. This was possible thanks to the potential and information scale of the LPIS about land and water use of each parcel of the territory.

In this sense, the results obtained confirm the initial approach: if we have a database in which we can structure the elements of fragmentation, we can see significant differences in the results related to the factors described above. Landscape types with higher total fragmentation show a smaller difference compared to fragmentation with paved infrastructure only. These units are related to areas that tend to have an intensive agriculture profile, higher connectivity from paved roads and railways and a more significant presence of patches with artificial elements. Such units are in the central-east plains in the province, mainly related with "La Mancha" region, where intense agriculture uses are more frequent.

In contrast, the landscape units with the greatest difference between the IFI indices indicate areas with a high density of rural roads, in this case smaller and with less connective characteristics for agricultural uses and a tendency towards extensive uses. These results emphasise the RQ2 approach, which established the potential of the LPIS source for the development of landscape fragmentation analyses. From a technical point of view, this source allows us to develop the most common fragmentation indicators, incorporating not only the values themselves but also the qualitative interpretation associated with the land use that each polygon in the source provides. We are able to recognise the value of the different land uses and relate it to the result of the fragmentation. In other words, we can approach the assessment of different patterns of agricultural use and connect it to the debate on landscape fragmentation and integration. Nevertheless, we claim a more attention about some LPIS land use categories, like "improductivo" (unproductive land use) or "elementos del paisaje" (landscape elements). In both categories, it would be advisable to achieve a more concise definition of the elements included.

This is something we can see in the analysis of the different fragmentation layers related to UFI. In this case, we test the impact of urban uses besides urban settlements, including non-agrarian land uses, fenced areas and isolated buildings and facilities. All of them contribute to landscape fragmentation since are indicative of processes and activities different from the cultural character. Once again, the more dynamic areas in plains showed higher proportion of such patches, demonstrating a more heterogeneous mixture of uses and a more fragmented pattern. On the other hand, areas in the periphery, mountainy peripheries and transitional landscapes showed a lower proportion of such uses. Together with a more impact of minor rural roads we can determine that they contribute to the structure and consolidation of the rural matrix, and its change cause fragmentation, while its presence can be considered a cohesion factor for cultural landscapes.

In comparison to other application of CILF by De Montis et al. [41] our input shows a different perspective. Because of the nature of the LPIS data source we introduced infrastructures as areas instead of lines and land use information allowed us to qualify the nature of landscape fragmentation. On the other hand, we are not able to add a temporal perspective, which is a limitation as we comment in the next section. Additionally, the scale of our analysis allows a high detail since the data source refers to parcels.

\section{Conclusions}

The fragmentation of cultural landscapes is a phenomenon that can be interpreted as a gradient and in different ways depending on the factors considered. The heterogeneity of these spaces generates different dynamics, whereby some uses affect others and, consequently, there will be fragmentation. Serrano et al. [7] pointed out that fragmentation is the loss of landscape connectivity, but this consideration is limiting in the context of cultural landscapes, which are characterised by the multifunctionality of their elements and the difficult balance between these. For these authors, agriculture is an agent of fragmentation, as are transport infrastructure and urban development. In our opinion, these processes have an ambivalent interpretation in cultural landscapes, since fragmentation is 
a dual process that generates disintegration and cohesion at the same time. Our results showed that those units with a more traditional structure have a considerable proportion of fragmentation due to the minor rural network. In our opinion, such fragmentation must be interpreted qualitatively because, in fact, it contributes to spatial cohesion of the rural matrix and, consequently, to the structure of the cultural landscape.

Fragmentation, understood from a dynamic and multifunctional approach, speaks of the dynamics of the landscape in all its components, it speaks of internal heterogeneity in relation to uses that become dominant at the expense of others that are reduced and isolated, whether natural or cultural, or even both [10]. Elements such as major roads, railways, urban settlements and specific land uses with activities with higher fragmentation impact (solar power plants, fenced activities) constitute a land use change which affects also to the cultural landscape of these units.

Our study approach shows limitations, land use change is a slow process, so including a temporal perspective and dynamics is complex with our data source and more detail can be added conducting a sensitivity analysis on factors and weighting the indicators, including to achieve more accuracy measuring landscape fragmentation. The use of the LPIS data offered us a highly detailed source that we approached to test our hypothesis, but is also much focused on agriculture elements, reducing its usefulness when urban dynamics are important, for example where solar power plants appear (these facilities are strong elements of fragmentation and tend to aggregate in the territory). We are aware that the potential of it opens several options for further investigation, along with a more in-depth analysis of the factors analysed here. Land use and its relationship with landscape fragmentation might be further explored in the search of relations between land use activities and landscape structures, not only fragmentation. This reveals the usefulness of the LPIS for obtaining results that can be applied to strengthen knowledge about landscape character and structure, but also to obtain useful indicators in landscape management and applying the ELC.

Author Contributions: Conceptualization, J.P.T. and H.S.M.S.-M.; methodology, J.P.T. and H.S.M.S.M.; formal analysis, J.P.T.; writing — original draft preparation, J.P.T. and H.S.M.S.-M.; writing—review and editing, H.S.M.S.-M.; visualization and supervision, J.P.T. All authors have read and agreed to the published version of the manuscript.

Funding: This research was funded by the Autonomous Region of Castilla-La Mancha and FEDER (EU), research project “Los Paisajes Culturales Agrarios en Castilla-La Mancha como base del desarrollo territorial" grant number SBPLY/19/180501/000041.

Institutional Review Board Statement: Not applicable.

Informed Consent Statement: Not applicable.

Acknowledgments: The authors want to thank the support of the DETER research group and CETI research centre of the University of Castilla-La Mancha (Spain).

Conflicts of Interest: The authors declare no conflict of interest. 


\section{Appendix A}

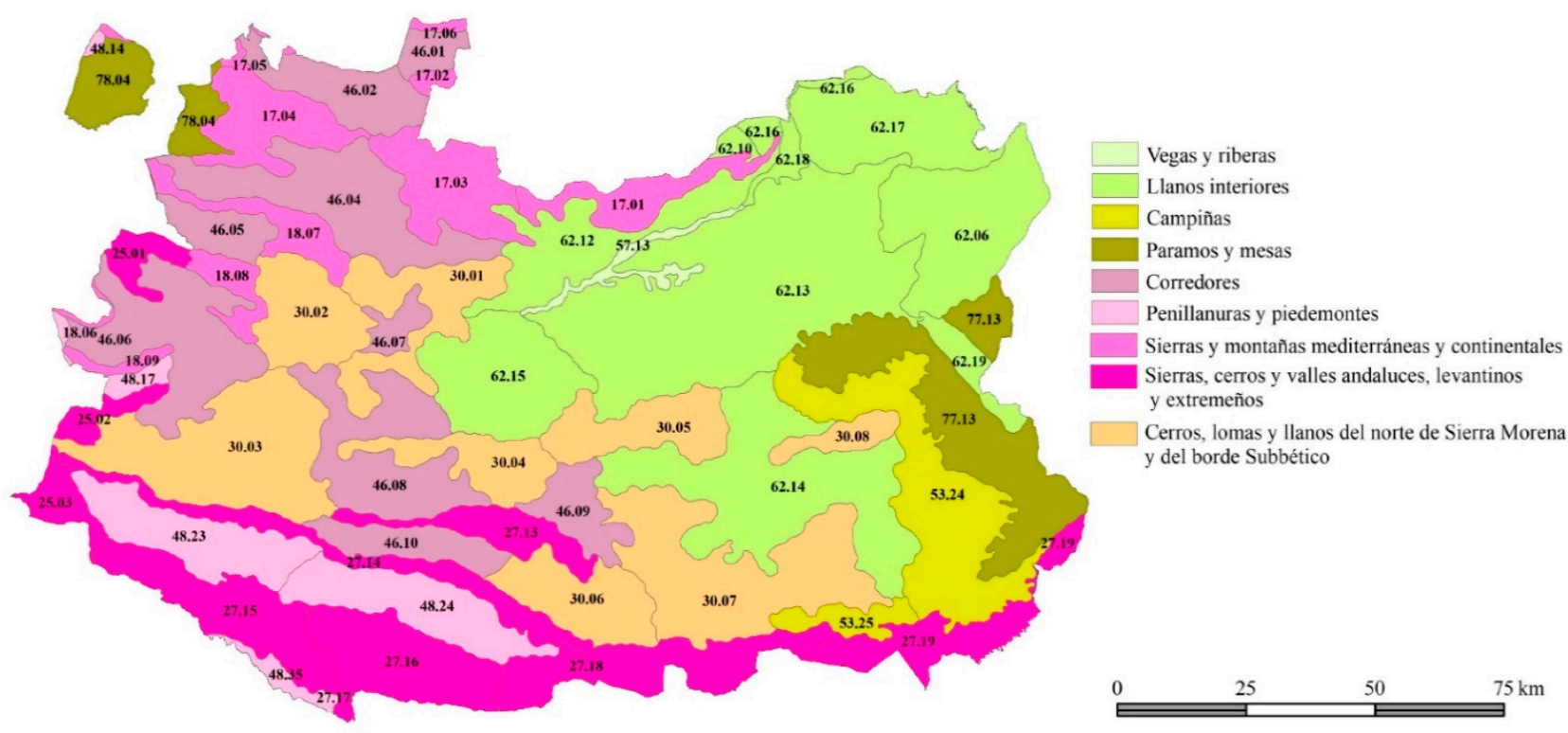

Land units: 17.01, Sierras de la Calderina y Reventón. 17.02, Sierras de las Guadalerzas. 17.03, Sierras del Pocito-Malagón. 17.04, Sierra del Chorito. 17.05, Los Montes de Toledo. 17.06, Sierra de los Yébenes. 18.06, Sierras de los Golondrinos y la Chimenea. 18.07, Sierra de la Lobera. 18.08, Sierra de En Medio y Puerto Quemado. 18.09, Sierra de Valdemanco del Esteras. 25.01, Sierras de la Rinconada y la Umbría. 25.02, Sierra de Siruela. 25.03, Sierras del Torozo y de la Moraleja. 27.13, Sierra de Calatrava. 27.14, Sierra de Puertollano y Solana de Alcudia. 27.15, Sierra de la Umbría de Alcudia. 27.16, Sierra Madrona. 27.17, La Loma de las Pilas y del Alcornocal. 27.18, Sierras entre los ríos Jándula y Guadalén. 27.19, Sierra Morena Oriental. 30.01, Cerros del noroeste del Campo de Calatrava. 30.02, Cerros en San Carlos del Valle. 30.03, Cerros entre Almadén y Abenójar. 30.04, Cerros de Ballesteros y Caracuel de Calatrava. 30.05, Llanos y cerros del Campo de Calatrava. 30.06, Cerros y valle del Ojailén. 30.07, Cerros y sierras del oeste de Piedrabuena. 30.08, Cerros y valles de Santa Cruz de Mudela-El Viso del Marqués. 46.01, Pasillo del río Milagro. 46.02, Pasillo del río Bullaque. 46.04, Pasillo de Porzuna-Alcoba. 46.05, Depresión de Arroba de los Montes. 46.06, Pasillos de la Puebla de Don Rodrigo, Agudo y Saceruela. 46.07, Depresión de Piedrabuena. 46.08, Pasillos de Almodóvar del Campo y Corral de Calatrava. 46.09, Pasillo de Calzada de Calatrava. 46.10, Pasillo de Brazatortas-Puertollano. 48.14, Penillanura de la Jara. 48.17, Penillanura de Siruela. 48.23, Penillanura del Valle de Alcudia en Alamillo. 48.24, Penillanura del Valle de Alcudia en Mestanza. 48.35, Los Pedroches surorientales. 53.24, Campiña occidental del Campo de Montiel. 53.25, Campiñas en Castellar de Santiago. 57.13, Vega del Guadiana-Cigüela y Tablas de Daimiel. 62.06, Llanos de Socuéllanos-Villarrobledo. 62.10, Llanos de Turleque-Madridejos. 62.12, Llanos de Malagón. 62.13, Mancha de Ciudad Real en Manzanares-Daimiel-Tomelloso. 62.14, Llanos de Valdepeñas. 62.15, Llanos de Ciudad Real. 62.16, Llanos de Lillo-Villacañas. 62.17, Llanos de Alcázar de San Juan y Pedro Muñoz. 62.18, Depresión endorreica del Cigüela-Záncara. 62.19, Lagunas de Ruidera. 77.13, Parameras del Campo de Montiel. 78.04, La Raña de Anchuras.

Figure A1. Landscape units and associations in the province of Ciudad Real. 


\section{Appendix B}

Table A1. Summary of Land Fragmentation Indicators.

\begin{tabular}{|c|c|c|c|c|c|c|c|c|c|c|}
\hline Landscape Associations & $\begin{array}{l}\text { IFI }_{\text {Total }} \\
\text { (Average) }\end{array}$ & $\begin{array}{l}\text { IFI }_{\text {Paved }} \\
\text { (Average) }\end{array}$ & $\begin{array}{l}\text { \% IFI } \\
\text { /IFI } \\
\text { Total }\end{array}$ & $\begin{array}{l}\text { UFI }_{\text {Total }} \\
\text { (Average) }\end{array}$ & $\begin{array}{c}\mathrm{UFI}_{\mathrm{Urb}} \\
\text { (Average) }\end{array}$ & $\begin{array}{l}\% \mathrm{UFI}_{\mathrm{Urb}} \\
/ \mathrm{UFI}_{\text {Total }}\end{array}$ & $\begin{array}{c}\text { Seff } \\
\text { (Average) }\end{array}$ & $\begin{array}{l}\text { CILF }_{\text {Total }} \\
\text { (Average) }\end{array}$ & $\begin{array}{l}\mathrm{CILF}_{\mathrm{Urb}} \\
\text { (Average) }\end{array}$ & $\begin{array}{c}\% \\
\mathrm{CILF}_{\mathrm{Urb} /} \mathrm{CILF}_{\text {Total }}\end{array}$ \\
\hline Llanos interiores/Inland plains & $40,284,866.3$ & $35,282,441.6$ & $87.6 \%$ & 0.2097 & 0.1224 & $58.4 \%$ & 0.0256 & 20.6558 & 19.4641 & $94.2 \%$ \\
\hline Campiñas/Sedimentary hills with openfields & $21,071,416.5$ & $14,695,732.5$ & $69.7 \%$ & 0.0558 & 0.0304 & $54.5 \%$ & 0.027 & 13.3822 & 11.4908 & $85.9 \%$ \\
\hline Paramos y mesas/Paramos and mesas & $9,743,665.0$ & $4,740,905.0$ & $48.7 \%$ & 0.0197 & 0.0137 & $69.5 \%$ & 0.0122 & 6.0356 & 5.1391 & $85.1 \%$ \\
\hline $\begin{array}{c}\text { Cerros, lomas y llanos del norte de Sierra Morena y } \\
\text { del borde Subbético/Continental and mediterranean hills } \\
\text { and mountains }\end{array}$ & $4,524,701.3$ & $3,449,452.6$ & $76.2 \%$ & 0.0212 & 0.0119 & $56.1 \%$ & 0.0064 & 3.5035 & 3.2422 & $92.5 \%$ \\
\hline Vegas y riberas/Flood Meadows and riverbanks & $2,169,260.0$ & $1,649,690.0$ & $76.0 \%$ & 0.0608 & 0 & $0.0 \%$ & 0.003 & 3.3712 & 0.3199 & $9.5 \%$ \\
\hline Penillanuras y piedemontes/Peneplains and piedmonts & $560,302.4$ & $436,446.8$ & $77.9 \%$ & 0.0063 & 0.0033 & $52.4 \%$ & 0.0026 & 0.9341 & 0.8127 & $87.0 \%$ \\
\hline $\begin{array}{l}\text { Sierras, cerros y valles andaluces, levantinos y } \\
\text { extremeños/Mountains, hills and valleys in Andalucia }\end{array}$ & $1,267,546.7$ & $926,860.1$ & $73.1 \%$ & 0.0114 & 0.0084 & $73.7 \%$ & 0.0067 & 0.8541 & 0.7608 & $89.1 \%$ \\
\hline $\begin{array}{c}\text { Sierras y montañas mediterráneas y } \\
\text { continentales/Hills and plains in the north of Sierra } \\
\text { Morena and Subbetic boundaries }\end{array}$ & $418,145.4$ & $318,637.4$ & $76.2 \%$ & 0.0047 & 0.003 & $63.8 \%$ & 0.0035 & 0.4649 & 0.3822 & $82.2 \%$ \\
\hline
\end{tabular}




\section{References}

1. Cosgrove, D.; Daniels, S. The Iconography of Landscape. Essays on the Symbolic Representation, Design and Use of Past Environments; Cambridge University Press: Cambridge, UK, 1988.

2. Dejeant-Pons, M. The European Landscape Convention. Landsc. Res. 2006, 31, 363-384. [CrossRef]

3. Jongman, R.H.G.; Bunce, R.G.H. Landscape classification, scales and biodiversity in Europe. In Consequences of Land-Use Changes. Advances in Ecological Sciences 5; Jongman, R.H.G., Mander, Ü., Eds.; WIT Press: Southampton, UK, 2000; pp. 11-38.

4. Llausàs, A.; Nogué, J. Indicators of landscape fragmentation: The case for combining ecological indices and the perceptive approach. Ecol. Indic. 2012, 15, 85-91. [CrossRef]

5. Jaarsma, C.F. Approaches for the planning of rural road networks according to sustainable land use planning. Landsc. Urban Plan. 1997, 39, 47-54. [CrossRef]

6. Mennella, V.G.G.; Neri, M.; Menconi, M.E.; Vizzari, M. Propuesta de una nueva metodología para la ubicación de infraestructuras viarias ambientalmente sostenibles. Aplicación en el tramo viario de la pedemontana Fabriano-Muccia. Informes de la Constr. 2010, 62, 101-112. [CrossRef]

7. Serrano, M.; Sanz, L.; Puig, J.; Pons, J. Landscape fragmentation caused by the transport network in Navarra (Spain): Two-scale analysis and landscape integration assessment. Landsc. Urban Plan. 2002, 58, 113-123. [CrossRef]

8. Forman, R.T.T. Land Mosaics: The Ecology of Landscapes and Regions; Cambridge University Press: Cambridge, UK, 1995.

9. EEA. Landscape Fragmentation in Europe; European Environment Agency: Copenhagen, Denmark, 2011. [CrossRef]

10. Gulinck, H.; Wagendorp, T. References for fragmentation analysis of the rural matrix in cultural landscapes. Landsc. Urban Plan. 2002, 58, 137-146. [CrossRef]

11. Meentemeyer, V. Geographical perspectives of space, time, and scale. Landsc. Ecol. 1989, 3, 163-173. [CrossRef]

12. Sayre, N.F. Ecological and geographical scale: Parallels and potential for integration. Prog. Hum. Geogr. 2005, 29, 276-290. [CrossRef]

13. Asubonteng, K.O.; Pfeffer, K.; Ros-Tonen, M.A.; Baud, I.; Benefoh, D.T. Integration versus segregation: Structural dynamics of a smallholder-dominated mosaic landscape under tree-crop expansion in Ghana. Appl. Geogr. 2020, 118, 102201. [CrossRef]

14. Forman, R.T.T.; Godron, M. Landscape Ecology; John Wiley \& Sons: Hoboken, NJ, USA, 1986.

15. Lambin, E.F.; Turner, B.L.; Geist, H.J.; Agbola, S.B.; Angelsen, A.; Bruce, J.W.; Coomes, O.T.; Dirzo, R.; Fischer, G.; Folke, C.; et al. The causes of land-use and land-cover change: Moving beyond the myths. Glob. Environ. Chang. 2001, 11, 261-269. [CrossRef]

16. Kaplan, J.O.; Krumhardt, K.M.; Zimmermann, N. The prehistoric and preindustrial deforestation of Europe. Quat. Sci. Rev. 2009, 28, 3016-3034. [CrossRef]

17. Jongman, R. Homogenisation and fragmentation of the European landscape: Ecological consequences and solutions. Landsc. Urban Plan. 2002, 58, 211-221. [CrossRef]

18. Vizzari, M.; Sigura, M. Landscape sequences along the urban-rural-natural gradient: A novel geospatial approach for identification and analysis. Landsc. Urban Plan. 2015, 140, 42-55. [CrossRef]

19. Bowman, J.; Fahrig, L.; Cappuccino, N. Patch Size and Population Density: The Effect of Immigration Behavior. Conserv. Ecol. 2002, 6, 9. Available online: https://www.ecologyandsociety.org/vol6/iss1/art9/ (accessed on 1 February 2021). [CrossRef]

20. Law, B.S.; Dickman, C.R. The use of habitat mosaics by terrestrial vertebrate fauna: Implications for conservation and management. Biodivers. Conserv. 1998, 7, 323-333. [CrossRef]

21. Di Giulio, M.; Holderegger, R.; Tobias, S. Effects of habitat and landscape fragmentation on humans and biodiversity in densely populated landscapes. J. Environ. Manag. 2009, 90, 2959-2968. [CrossRef]

22. De Montis, A.; Ganciu, A.; Cabras, M.; Bardi, A.; Mulas, M. Comparative ecological network analysis: An application to Italy. Land Use Policy 2019, 81, 714-724. [CrossRef]

23. De Montis, A.; Martín, B.; Ortega, E.; Ledda, A.; Serra, V. Landscape fragmentation in Mediterranean Europe: A comparative approach. Land Use Policy 2017, 64, 83-94. [CrossRef]

24. Girvetz, E.H.; Thorne, J.H.; Berry, A.M.; Jaeger, J.A. Integration of landscape fragmentation analysis into regional planning: A statewide multi-scale case study from California, USA. Landsc. Urban Plan. 2008, 86, 205-218. [CrossRef]

25. Farina, A. Principles and Methods in Landscape Ecology; Springer: Berlin/Heidelberg, Germany, 2006.

26. Saunders, D.A.; Hobbs, R.J.; Margules, C.R. Biological Consequences of Ecosystem Fragmentation: A Review. Conserv. Biol. 1991, 5, 18-32. [CrossRef]

27. Jaeger, J.A.; Bertiller, R.; Schwick, C.; Müller, K.; Steinmeier, C.; Ewald, K.C.; Ghazoul, J. Implementing Landscape Fragmentation as an Indicator in the Swiss Monitoring System of Sustainable Development (Monet). J. Environ. Manag. 2008, 88, 737-751. [CrossRef] [PubMed]

28. EEA. Landscape Fragmentation Pressure and Trends in Europe; European Environment Agency: Copenhagen, Denmark, 2019.

29. Kosmas, C. Land Abandonment. Desertification Indicator System for Mediterranean Europe. 2005. Available online: https: / / esdac.jrc.ec.europa.eu/public_path/shared_folder/projects/DIS4ME/issues/issue_land_abandonment.htm (accessed on 25 March 2021).

30. García-Ruiz, J.; Lasanta, T.; Nadal-Romero, E.; Lana-Renault, N.; Álvarez-Farizo, B. Rewilding and restoring cultural landscapes in Mediterranean mountains: Opportunities and challenges. Land Use Policy 2020, 99, 104850. [CrossRef]

31. Taylor, P.D. Fragmentation and cultural landscapes: Tightening the relationship between human beings and the environment. Landsc. Urban Plan. 2002, 58, 93-99. [CrossRef] 
32. OECD. Economic Design of Low-Traffic Roads; Organisation for Economic Co-operation and Development: Paris, France, 1986; ISBN 9789264128828.

33. Marcantonio, M.; Rocchini, D.; Geri, F.; Bacaro, G.; Amici, V. Biodiversity, roads, \& landscape fragmentation: Two Mediterranean cases. Appl. Geogr. 2013, 42, 63-72. [CrossRef]

34. Pauwels, F.; Gulinck, H. Changing minor rural road networks in relation to landscape sustainability and farming practices in West Europe. Agric. Ecosyst. Environ. 2000, 77, 95-99. [CrossRef]

35. Amato, F.; Martellozzo, F.; Nolè, G.; Murgante, B. Preserving cultural heritage by supporting landscape planning with quantitative predictions of soil consumption. J. Cult. Herit. 2017, 23, 44-54. [CrossRef]

36. Castillo Ruiz, J. Carta de Baeza sobre Patrimonio Agrario; Universidad Internacional de Andalucía (UNIA): Seville, Spain, 2013.

37. Wade, M.; López-Gunn, E. Wetlands conservation. In Applied Geography: Principles and Practice; Pacione, M., Ed.; Routledge: Oxford, UK, 1999; pp. 288-300. ISBN 9781134672646.

38. Ruiz Pulpón, A.R. Dinámicas demográficas y cohesión social en Castilla-La Mancha. In Policentrismo y Áreas Funcionales de Baja Densidad; Pillet, F., Cañizares, M.C., Eds.; Síntesis: Madrid, Spain, 2017; pp. 117-138. ISBN 9788491710653.

39. Mata Olmo, R.; Sanz Herráiz, C. Atlas de los Paisajes de España; Ministerio de Medio Ambiente: Madrid, Spain, 2003; ISBN 9788483202937.

40. Lambin, E.F. Modelling and monitoring land-cover change processes in tropical regions. Prog. Phys. Geogr. Earth Environ. 1997, 21, 375-393. [CrossRef]

41. De Montis, A.; Serra, V.; Ganciu, A.; Ledda, A. Assessing Landscape Fragmentation: A Composite Indicator. Sustainability 2020, 12, 9632. [CrossRef]

42. OECD. Handbook on Constructing Composite Indicators: Methodology and User Guide; Organisation for Economic Co-operation and Development: Paris, France, 2008; ISBN 978-92-64-04345-9.

43. Nardo, M.; Saisana, M. Handbook on Constructing Composite Indicators. Putting Theory into Practice; OECD/JRC: Paris, France, 2009; ISBN 978-92-64-04345-9.

44. Ledda, A.; De Montis, A. Infrastructural landscape fragmentation versus occlusion: A sensitivity analysis. Land Use Policy 2019, 83, 523-531. [CrossRef]

45. Jaeger, J.A. Landscape division, splitting index, and effective mesh size: New measures of landscape fragmentation. Landsc. Ecol. 2000, 15, 115-130. [CrossRef] 